\title{
Natural Theology and Science in Contemporary Apologetic Context: An Overview
}

\author{
Peter S. Williams \\ Assistant Professor in Communication and Worldviews \\ NLA University College, Kristiansand, Norway \\ peterswilliams@gmail.com
}

\begin{abstract}
This essay offers some context to this Supplement edition of Theofilos, which presents peer reviewed papers resulting from the 2018 NLA Gimlekollen Symposium on the theme of 'Science, Natural Theology, and Christian Apologetics'. I review something of the history of natural theology and of natural philosophy (i.e. science), discuss objections to natural theology from theological and philosophical critics, review some key developments within the field of natural theology (especially as it relates to science), and end with some advice on natural theology and Christian apologetics in an age of science.
\end{abstract}

Keywords: Natural Theology, Science, Apologetics, Philosophy, Spirituality

\section{Science, Natural Philosophy, and Natural Theology \\ In his 'Address to the Clergy', John Wesley (1703-1791) urged:}

Some knowledge of the sciences also, is ... expedient ... the knowledge of one ... is even necessary ... I mean logic. For what is this, if rightly understood, but the art of good sense, of apprehending things clearly, judging truly, and reasoning conclusively? What is it, viewed in another light, but the art of learning and teaching; whether by convincing or persuading? What is there, then, in the whole compass of science, to be desired in comparison of it? . . . Should not a

\begin{abstract}
Minister be acquainted too with at least the general grounds of natural philosophy? Is not this a great help to the accurate understanding of several passages of Scripture? Assisted by this, he may himself comprehend, and on proper occasions explain to others, how the invisible things of God are seen from the creation of the world; how 'the heavens declare the glory of God, and the firmament showeth his handiwork;' till they cry out, 'O Lord, how manifold are thy works! In wisdom hast thou made them all.' 1
\end{abstract}

To grasp the meaning of Wesley's advice, it helps to know that the Latin word scientia (from which we derive the word 
'science') simply meant 'knowledge'. For scholars from classical times until the nineteenth century, every academic discipline that laid claim to knowledge was by definition scientific. This included the sciences of theology ('the queen of sciences') and theology's 'handmaid' philosophy; the latter being a broad subject that included the sub-disciplines of rhetoric (and thus logic), natural philosophy (inquiry into the physical cosmos), and the making of arguments for God's existence (a discipline called natural theology).

Whilst the scriptures quoted by Wesley (Romans 1:18-20, Psalm 19) may be read as affirming that God can be intuitively perceived through contemplating creation, rather than as affirming that good arguments can be constructed linking creation to God (a matter of 'general revelation' rather than 'natural theology'2), they at least lay a foundation conducive to natural theology. Another scripture worth noting in this context is Paul's speech to the Lycaonians (Acts 14:15-17). ${ }^{3}$ As Norman L. Geisler writes: 'It should not seem strange to those who believe in God's manifestation in His creation (Rom. 1:19-29; Ps. 19:1) that it is possible to arrive at knowledge of God by inference from these manifestations.'4

\section{Natural Theology and Theology of Nature}

British scientist turned theologian Alister McGrath advocates a 'theology of nature' defined as 'a Christian understanding of the natural world that reflects the core assumptions of the Christian faith.' $5 \mathrm{He}$ explains:

The trajectory of thought here is from within the Christian tradition towards nature rather than from nature towards faith. This theology of nature is often expressed particularly in terms of the doctrine of creation ... The Christian faith is here understood to provide an interpretative framework by which nature may be seen in profound and significant ways ... like a lens bringing a vast landscape into sharp focus, or a map helping us grasp the features of the terrain around us. ${ }^{6}$

For McGrath, a 'theology of nature' isn't opposed to 'natural theology', but a way of approaching it:

The capacity of the Christian vision of reality to 'fit in' so much of what we see around us and experience within us ... can be seen as an indication of both its truth and its trustworthiness. Christianity makes sense of what we know about the history of the cosmos, especially the curious phenomenon of fine tuning. It helps make sense of the complexity of human nature, including our propensity to failure and self-delusion on the one hand and our genuine aspirations to goodness on the other. ${ }^{7}$

McGrath prefers this approach to natural theology over others because it's in sympathy with his preferred apologetic methodology: 'My approach is more like a scientist than a philosopher,'8 explains McGrath, 'I would describe my approach as 'inductive' or 'abductive' . . .'9 Indeed, McGrath extols 'a new style of natural theology adapted to the methods of natural science rather than conforming to the conventions of the philosophy of religion.'10 However, this latter distinction rests on a caricature of 'the philosophy of religion' as exclusively concerned with deductive arguments which claim 'to prove the existence of God'.11

On the one hand, contemporary philosophers of religion generally recognize 
that, in most contexts, including natural theology, there is no such thing as a rationally coercive argument. As Stephen T. Davis observes: 'few arguments are intellectually coercive ...'12 Indeed, Alvin Plantinga comments that:

A person might, when confronted with an argument he sees to be valid for a conclusion he deeply disbelieves from premises he knows to be true, give up (some of) those premises: in this way you can reduce someone from knowledge to ignorance by giving him an argument he sees to be valid from premises he knows to be true. ${ }^{13}$

In other words, the effectiveness of an argument is person-relative. ${ }^{14}$

On the other hand, natural theology has long incorporated arguments beyond the stereotypical 'proofs' of medieval scholasticism. For example, F.C. Copleston advanced a 'best explanation'15 argument from religious experience in his 1948 debate with Bertrand Russell. F.R. Tennant made a cumulative argument from 'cosmic teleology' in the second volume of his Philosophical Theology (Cambridge University Press, 1930).16 William Paley's famous 'watch-maker' argument from the early nineteenth century was framed as an inference (though it's often incorrectly portrayed as an argument by analogy). ${ }^{17}$ Blaise Pascal formulated an abductive version of the argument from desire in his seventeenth century Pensées. ${ }^{18}$. Even Thomas Aquinas' 'Five Ways' from Summa Theologica included an argument (i..e the 'fifth way') resting upon the inference that 'natural bodies, act for an end, and this is evident from their acting always, or nearly always, in the same way, so as to obtain the best result.'19

Moreover, twentieth century philoso- phers of religion explicitly imitated argumentative strategies from the natural sciences in natural theology. For example, Basil Mitchel used an analysis of scientific rationality in pursuit of The Justification of Religious Belief (Macmillan, 1973). Richard Swinburne's influential natural theology likewise takes its cues from scientific inferences and is famously structured using Bayes' probability theorem. ${ }^{20}$

In the final analysis, a preference for a given apologetic methodology cannot overrule the need to judge every purported argument for God on its individual merits, regardless of its logical form.

\section{Natural Theology Under Fire}

The project of natural theology, stretching at least as far back as the ancient Greeks ${ }^{21}$, came under fire in the early twentieth century from both within and without Christianity. 22

\section{Natural Theology Takes a Cold Bath}

In the theology of Karl Barth, not only was natural theology 'set against the revealed religion of Christ in Scripture' due in part to the former's historical linkage 'with German national Volk-religion', but 'biblical theology became isolated from rationality, presupposing its own truth ...23 Barth held that knowledge of God comes only through special revelation:

God in his sovereignty makes himself knowable. Man in his sinfulness cannot otherwise obtain any knowledge of God. A great gulf is fixed, bridged only by God in disclosing himself in Christ through the work of the Holy Spirit. Such knowledge is entirely a work of grace, unaided by human intellect. ${ }^{24}$

As Peter May goes on to explain, Barth:

did not believe in arguments or evidences to proclaim Christianity, 
and his influence persists strongly today. Such rational approaches to belief could in his view do nothing to facilitate a personal encounter with Christ. The evidence of nature and apologetic reasoning had no role in bringing people to faith. In his view, such rational thought could only be of benefit for those who already believed in God, and such belief could only come about by God's revelation of himself. ${ }^{25}$

As creator, God obviously takes the initiative in making himself knowable to humanity. However, to say that human (Godgiven) reasoning plays no role in bringing people to knowledge of or to faith in God/Christ, flies in the face of plentiful scriptural evidence to the contrary (e.g. Exodus 7:5; Ezekiel 25:11; John 14:11 \& 20:29-31; Acts 1:3, 2:1-42, 9:22, 14:1517 \& 17:30-31; Romans 1:17-19; 1 Peter $3: 15)^{26}$, as well as plentiful testimony from people whose belief in God and/or commitment to Christ was at least partially facilitated by Christian apologetics. ${ }^{27}$ As a case in point, I was delighted to receive an e-mail from Venezuela some years ago offering testimony that:

as a graduate student of philosophy, I'm a eager reader of your books and online articles, which have been instrumental in my rejection of agnosticism and naturalism and have contributed strongly to make me a new-born Christian.

\section{Once upon a time in Vienna}

There was a time, in the early twentieth century, when thinking about God was nearly banished from academia because of the many academics who thought that talk about 'God' was literally meaningless. They thought that 'God-talk' made no sense beyond its emotive content. 'God' wasn't the only subject to suffer such banishment. Assertions about right and wrong, beauty and ugliness - all statements that were metaphysical in nature - were widely considered to be literally nonsense.

The enforcer of this philosophical dress code was the now infamous 'verification principle' sponsored by a group of thinkers known as 'logical positivists'. Kelly James Clark explains that logical positivism: 'began in the early 1920s in an informal discussion group in Austria called the Vienna Circle. The original members, led by physicist Moritz Schlick, included mathematicians, physicists, sociologists and economists but no professional philosophers.'28 This omission was unfortunate, because: 'United by their passionate dislike of the metaphysical ... the group developed a unified philosophy that embraced science and attempted to destroy philosophy.'29 Attempting to develop a unified philosophy that dispenses with philosophy makes about as much sense as Groucho Marx's comment that he wouldn't belong to any club that would have him as a member. Nevertheless, the ideas of the Vienna Circle spread far and wide.

\section{The Circle of Exclusion}

Despite some disagreement among the members of the Vienna Circle, 'there was an initial impulse to accept the verification theory of meaning. . .'30 This theory held that any statement that wasn't true by definition (e.g. 'all bachelors are unmarried men') was only meaningful if it could be empirically verified (at least in principle). To 'empirically verify' something means to check it out with the physical senses (sight, hearing, touch, etc.), at least indirectly. In other words, the statement 'This is a book' is meaningful, because you can verify it by seeing, 
hearing, touching, smelling and/or tasting the book; but a statement like 'That sunset is beautiful' is not meaningful because you can't verify it's meaning by seeing, hearing, touching, smelling or tasting the 'beauty' of the sunset. Likewise, positivists hold that the statement 'God exists' cannot be verified and is therefore meaningless, a use of language on a par with nonsense poetry (like the parts of 'Jabberwocky' that Lewis Carroll didn't define ${ }^{31}$ ). It may have an emotional resonance, but it has no rational content that can be understood or judged as being an accurate or inaccurate representation of reality.

\section{The Influence of Language, Truth \& Logic}

The primary importer of logical positivism into Britain, and hence into AngloAmerican analytic philosophy, was A.J. Ayer (1910-1989). Unlike the members of the Vienna Circle, Alfred Jules Ayer (known to his friends as 'Freddie') was a philosopher. Ayer studied philosophy at Oxford under Gilbert Ryle before becoming a professor himself, ending up back at Oxford for a time (1947-59).

Ayer was immersed in logical positivism during 1932 whilst studying (at Ryle's recommendation) with Moritz Schlick in Vienna. This visit filled the gap between Ayer's university finals and taking up his first lectureship. Two years later, Ayer started work on the book that would make his name: Language, Truth \& Logic (1936):

Ayer's philosophical ideas were largely parasitic on those of the Vienna Circle. However, his clear, vibrant and (arguably) arrogant exposition of them makes Language, Truth and Logic essential reading on the tenets of logical positivism - the book is a classic and is widely read in philosophy courses around the world. ${ }^{32}$
Ayer proclaimed:

The term 'God' is a metaphysical term. And if 'God' is a metaphysical term, then it cannot even be probable that a god exists. For to say that 'God exists' is to make a metaphysical utterance which cannot be either true or false. . . If a putative proposition fails to satisfy [the verification] principle, and is not a tautology, then. . . it is metaphysical, and ... being metaphysical, it is neither true nor false but literally senseless. ${ }^{33}$

As Ayer admitted, positivism entailed that the denial of God's existence was just as meaningless as the affirmation of his existence, atheism as irrational as theism: 'If the assertion that there is a god is nonsensical, then the atheist's assertion that there is no god is equally non-sensical.' 34

Likewise, according to Ayer:

Such aesthetic words as 'beautiful' and 'hideous' are employed, not to make statements of fact, but simply to express certain feelings and evoke a certain response. It follows, as in ethics, that there is no sense in attributing objective validity to aesthetic judgements, and no possibility of arguing about questions of value in aesthetics ... there is nothing in aesthetics, any more than there is in ethics, to justify the view that it embodies a unique type of knowledge. It should now be clear that the only information which we can legitimately derive from the study of our aesthetic and moral experiences is information about our own mental and physical make-up. 35

Copleston noted that 'Ayer's writings exercised a widespread influence, particularly perhaps on university students, for whom it possessed the charm of novelty and an atmosphere of daring.' 36 Ayer's declaration that God-talk is nonsense has influenced generations of scholars, despite 
the fact that his book originally only sold 'just over 1,000 copies (64 years later, the book still sells 2,000 a year in Britain: a 1945 reprint in the United States has sold 300,000).'37 As Hilary Spurling observes:

It was one of those books that galvanize a whole generation. Ambitious undergraduates commonly read it at a sitting. Their elders were appalled. When students tried to discuss the book at an Oxford seminar, the Master of Balliol flung it through the window. Ayer was denounced by a housemaster at Winchester School as the wickedest man in Oxford. Asked what came next, the young iconoclast said cheerfully: 'There's no next. Philosophy has come to an end. Finished.'38

However, within a few of decades it became clear that philosophy had not come to an end and that positivism was 'finished', at least within academic philosophy. In 1943, E.L. Mascall observed that 'the logical positivists' position seems to be crumbling from within . . .'39 Two decades after Language, Truth and Logic was published, Copleston wrote: 'There are few British philosophers who willingly accept the title of 'positivists' or who make open profession of applying the principle of verifiability as a criterion of meaning . . . [Positivism] is no longer fashionable.'40 In The Cosmological Argument: A Reassessment (Charles C. Thomas, 1972), Bruce R. Reichenbach commented: 'The era is past when all metaphysical statements or arguments can simply be dismissed as silly or senseless, since they do not meet a pre-established criterion of verifiability.' 41 Despite being a dead issue in academic philosophy, the ghost of positivism continues to inspire uninformed attacks upon philosophy in general and natural theology in particular.

\section{A Negative Assessment of Positivism}

A number of factors explain the near total demise of positivism.

Ironically for materialists who embraced logical positivism, 'materialism would have to be rejected as nonsense by a strict interpretation of logical positivism'. ${ }^{42}$. The claim that matter is objectively real is, after all, neither true by definition nor something that can be verified by sense data (since it's the nature of what the senses perceive that's in question).

Indeed, positivism makes not only materialism, but also a realist account of science, impossible. As Copleston argued:

if the meaning of an existential proposition consists, according to the principle, in its verifiability, it is impossible, I think, to escape an infinite regress, since the verification will still itself need verification, and so on indefinitely. If this is so, then all [existential] propositions, including scientific ones, are meaningless. ${ }^{43}$

In an article published in 1960, philosopher John Hick pointed out that, when made precise enough, the statement that 'God exists' is, in principle at least, indirectly verifiable. Hick argued that:

A set of expectations based upon faith in the historic Jesus as the incarnation of God, and in his teaching as being divinely authoritative, could be so fully confirmed in postmortem experience as to leave no grounds for rational doubt as to the validity of that faith. ${ }^{44}$

If you were to die and then find yourself in a Christian afterlife - you are given a resurrected body and a life in a sinless community that revolves around the resurrected Jesus Christ - one could surely count this as an indirect verification of God's existence. Unless positivism is framed broadly enough to allow for indirect 
verification, many explanatory entities within science would count as nonsense, because they are verified indirectly. For example, scientific theories about so-called 'dark matter' would count as meaningless under a verification principle that excluded indirect verification. ${ }^{45}$ Again, just as empirical measurement of the background radiation of the universe provides indirect verification of the 'big bang' in cosmology (to see one isn't to see the other, but to see the one is to see something from which the other can be infer$\mathrm{red}^{46}$ ), so experiencing the sort of afterlife promised in the New Testament would likewise provide indirect empirical verification of God's existence. This being so, the claim that God exists is open to verification, in principle, and therefore counts as being a meaningful claim according to any principle of verification consistent with scientific practice.

In other words, the verification principle can't be used to wall off scientific claims about the universe from religious claims about its creator, because it either lets too much metaphysics or too little science into the category of 'claims that are meaningful'. As Llyod Eby observes: 'All attempts to solve this problem of having a version of the verification principle... that admits all scientific statements but excludes all metaphysical statements have met with failure.' ${ }^{47}$ Hence, as Hick concluded: 'the existence or non-existence of the God of the New Testament is a matter of fact, and claims as such eventual experiential verification.' 48

In 1967 American philosopher Alvin Plantinga published God and Other Minds, which 'applied the tools of analytic philosophy to questions in the Philosophy of Religion with an unprecedented rigour and creativity.' $49 \mathrm{He}$ argued by analogy with the rationality of belief in other minds (whose non-tautological existence can't be directly verified by empirical methods) that 'if my belief in other minds is rational, so is my belief in God.'50 But, of course, even verificationists generally believe in other minds.

Then, with the 1974 publication of The Nature of Necessity, Plantinga kickstarted a philosophical re-evaluation of theistic arguments by using modal logic to lay out a logically valid version of the ontological argument. ${ }^{51}$

Between them, God and Other Minds and The Nature of Necessity tackled both prongs of the positivist's proposed dilemma: Show that theism is either verifiable or tautologically true as a matter of definition, or else accept banishment to the outer darkness of meaninglessness. Plantinga responded to the first positivist prong that a demand for direct verification renders positivism self-contradictory, thereby opening up the possibility of arguments from indirect verification. To the second prong, Plantinga responded that, even if he can't prove that God's existence is tautologically true, he can prove that it is rational to think that God's existence is tautologically true, and that this fact is sufficient to demonstrate that God-talk is meaningful, for how can a truth-claim be rational without also being meaningful?

Exploiting the openings noted by Hick and Plantinga, philosophers such as Basil Mitchell and Richard Swinburne began to argue that the God hypothesis isn't merely indirectly verifiable in principle, but also in practice, since several arguments for God can be framed using the scientific method of indirect verification (e.g. arguments from miracles or from design). As Mitchell comments:

the Logical Positivist movement started as an attempt to make a clear demarcation between science 
and common sense on the one hand, and metaphysics and theology on the other. But work in the philosophy of science convinced people that what the Logical Positivists had said about science was not true, and, by the time the philosophers of science had developed and amplified their accounts of how rationality works in science, people discovered that similar accounts applied equally well to the areas which they had previously sought to exclude, namely theology and metaphysics. 52

Finally, as R. Douglas Geivett explains, philosophers noticed that the verification principle 'was neither empirically verifiable nor tautological.'53 That is, the verification principle was itself a metaphysical claim, a claim that therefore ruled itself to be meaningless: 'it failed its own requirement for factual meaningfulness', notes William P. Alston, 'and thus was self-refuting.' 54

Ayer tried to get around this problem by admitting that the verification principle wasn't a meaningful proposition but saying that it was a rule for using language. But why pay attention to such an arbitrary rule? Ayer himself asked: 'why should anyone follow the prescription if its implications were not to his taste?'55

Keith Ward reports the following conversation between Ayer and a student:

A student once asked [Ayer] if you could make any true general statement about meaningful statements. 'Yes,' he replied. 'You can say that all meaningful statements must be verifiable in principle.' 'I see what you mean,' said the student. 'But how can I verify that?' 'I am glad you asked that,' said the philosopher. 'You cannot verify it. But it is not really a meaningful statement; it is just a rule for using language.'
'Whose rule?' 'Well, it's my rule, really. But it is a very useful one. If you use it, you will find you agree with me completely. I think that would be very useful.' 56

If we adopt the rule, then of course we'll agree with Ayer, and of course he'll find that useful! But he can't provide us with a good reason for adopting his rule (certainly not one that doesn't implicitly contradict the rule he wants us to adopt). Instead, he recommends it on the basis of its usefulness. Usefulness for what? For insulating a worldview that excludes everything metaphysical, especially religion (as the positivist's failed attempts to produce a version of the principle able to draw a line of demarcation between science on the one hand religion on the other hand, shows). Indeed, it would seem that the motivation behind logical positivism was the desire to exclude God by excluding talk about God. Logical positivism was quite simply a form of atheistic censorship. However, philosophers who opposed this baseless peerpressure were well within their rights to point out that the Emperor of positivism had no clothes, but brazenly walked the halls of academia with nothing but a smile of fashionable popularity to disguise his embarrassingly self-contradictory ways.

James Kelly Clark describes the verification principle as a piece of 'unjustifiable philosophical imperialism that, in the end, could not survive critical scrutiny.' 57 William Lane Craig comments: 'Fifty years ago philosophers widely regarded talk about God as literally meaningless . . . but today no informed philosopher could take such a viewpoint.'58 Ronald H. Nash concludes that positivism is dead and quite properly so.' 59 Roger Scruton observes: 'Logical positivism no longer has a 
following, and it is easy to see why. The verification principle cannot be verified: it therefore condemns itself as meaningless.'60

By 1973 Ayer himself admitted: 'the verification principle is defective . . .'61 Talking about positivism during an interview in 1978, Ayer conceded: 'Nearly all of it was false.' 62 He reflected: 'I just stated [the verification rule] dogmatically and an extraordinary number of people seemed to be convinced by my assertion.' 63 In the end, Ayer conceded: 'Logical Positivism died a long time ago. I don't think much of Language, Truth and Logic is true. I think it is full of mistakes.' 64

\section{The Resurrection of God-Talk}

On 8 April 1966, Time Magazine ran a cover story about the then current 'deathof-God' movement in American theology entitled 'Is God Dead?' William Lane Craig explains that:

According to the movement's protagonists, traditional theism was no longer tenable and had to be once and for all abandoned. Ironically, however, at the same time that theologians were writing God's obituary, a new generation of young philosophers was rediscovered His vitality. 65

Only a few years later, Time carried a cover story asking 'Is God coming back to life?' Interest in the philosophy of religion continued to grow to the point where, in 1980, Time ran a story about 'Modernizing the case for God', describing the contemporary movement among philosophers putting new life into the arguments for God's existence:

In a quiet revolution in thought and argument that hardly anybody could have foreseen only two decades ago, God is making a come- back. Most intriguingly, this is happening not amongst theologians or ordinary believers, but in the crisp intellectual circles of academic philosophers, where the consensus had long banished the Almighty from fruitful discourse. 66

The reference to banishing the Almighty from fruitful discourse is a reference to positivism. It's no surprise to find Tyler Burge, Professor of philosophy at UCLA, writing that the central event in philosophy during the last half-century was 'the downfall of positivism and the re-opening of discussion of virtually all the traditional problems of philosophy.' 67 This philosophical renaissance went hand-in-hand with a revival of interest in natural theology amongst analytic philosophers of religion. As James Brent comments: 'Natural theology today is practiced with a degree of diversity and confidence unprecedented since the late Middle Ages.' ${ }^{68}$

\section{Defining 'Natural Theology'}

Thomas Aquinas famously distinguished between 'revealed (dogmatic) theology and rational (philosophical) theology,'69 writing in his Summa Contra Gentiles that:
there exists a twofold truth concer- ning the divine being, one to which the inquiry of the reason can reach, the other which surpasses the whole ability of the human reason, it is fit- ting that both of these truths be proposed to man divinely for be- lief. 70

Aquinas was not making a distinction between truths of reason in the domain of natural theology on the one hand and truths of blind faith on the other. Aquinas' meaning would have been clearer if he'd written that 'there exists a twofold truth concerning the divine being, one to which the inquiry of the reason unaided 
by special revelation can reach, the other which surpasses the whole ability of the human reason unaided by special revelation'. That this is what he meant becomes clear later in Summa Contra Gentiles, where he argues:

Those who place their faith in this truth, however, 'for which the human reason offers no experimental evidence,' do not believe foolishly . . . For these 'secrets of divine Wisdom' (Job 11:6) the divine Wisdom itself ... has deigned to reveal to men. It reveals its own presence, as well as the truth of its teaching and inspiration, by fitting arguments; and in order to confirm those truths that exceed natural knowledge, it gives visible manifestation to works that surpass the ability of all nature ... and what is more wonderful, there is the inspiration given to human minds, so that simple and untutored persons, filled with the gift of the Holy Spirit, come to possess instantaneously the highest wisdom . . .71 [my italics]

In other words, human reason is enabled to reach what it otherwise would not be able to reach - truths of special revelation which surpasses the ability of human reason unaided by special revelation - by the divine design to reveal these truths in such a manner that warrant is thereby provided for rational belief in them.

For Aquinas, this warrant is provided by the Holy Spirit, either quite aside from arguments, or in conjunction with the revelation of 'fitting arguments' and publicly accessible evidence of 'works that surpass the ability of all nature' (that is, miracles). Aquinas argues that the latter, argumentative warrant falls into the category of 'persuasive [i.e. non-deductive] reasoning' rather than that of 'demonstrative reasoning' which 'yields a conclusion that is undeniable for anyone who grasps the truth of the demonstration's premises' 72

Not only does Aquinas make a principled distinction between truths of reason (i.e. truths of natural theology accessible to reason unaided by special revelation) and truths of faith (truths of revealed theology accessible to human reason with the help of special revelation), but he claims to know where the line of this distinction runs:

$$
\begin{aligned}
& \text { Some truths about God exceed all } \\
& \text { the ability of the human reason. } \\
& \text { Such is the truth that God is triune. } \\
& \text { But there are some truths which the } \\
& \text { natural reason also is able to reach. } \\
& \text { Such are that God exists, that He is } \\
& \text { one, and the like. }{ }^{73}
\end{aligned}
$$

While it is wise to recognize that we will never comprehend God, I would argue that it is also wise not to think, with Aquinas, that we can discern in advance of trying to understand some theological topic that this or that topic 'surpasses the whole ability of the human reason' unaided by special revelation. Indeed, not only have Christian philosophers (e.g. Stephen T. Davies) given arguments against a Unitarian definition of $\mathrm{God}^{74}$, some have explicitly argued for God's Tri-unity (e.g. Richard of St Victor, Richard Swinburne and myself ${ }^{75}$ ).

Aquinas' demarcation between natural and revealed theology was highly influential, leading generations of thinkers to assume the existence of a principled division between these disciplines. For example, according to Hugh G. Gauch Jr.:

The task of natural theology is to reach the most significant truths available to unaided reason evaluating public evidence, in contrast to the greater truths available only to faith through a genuine revelation from God. 76 
However, on the one hand, significant truths that natural theologians routinely think 'available to unaided reason evaluating public evidence' can, of course, be taken on faith (treating 'faith' here as a synonym for 'trust'). For example, while advocates of natural theology often endorse cosmological arguments ${ }^{77}$, the author of Hebrews writes: 'By faith we understand that the universe was formed at God's command, so that what is seen was not made out of what was visible.' (Hebrews 11:3.) On the other hand, any 'greater truths available only ... through a genuine revelation from God' can only be the object of faith if human (Godgiven) 'reason' is set to the task of 'evaluating' the relevant revelation (for example, in understanding what a given scriptural passage means).

James F. Sennett and Douglas Groothuis define natural theology as:

The attempt to provide rational justification for theism using only those sources of information accessible to all inquirers, namely, the data of empirical experience and the dictates of human reason. In other words, it is defense of theism without recourse to purported special revelation. 78

Likewise, according to Scot MacDonald:

Natural theology aims at establishing truths or acquiring knowledge about God (or divine matters generally) using . . . standard techniques of reasoning and facts or truths in principle available to all human beings just in virtue of their possessing reason and sense perception. ${ }^{79}$

However, while purported special revelation about Jesus Christ was obviously unavailable to the 'empirical experience and ... reason' of, say, stone-age humans, so too were many cosmological and bio- logical discoveries that ground various contemporary arguments in natural theology (e.g. the 'Big Bang', the precision of cosmic 'fine tuning', the informational nature of life and the existence of molecular machines). Likewise, 'purported special revelation' about Jesus is just as 'accessible to all inquirers' today as are those cosmological and biological discoveries. And again, the purported 'special revelation' available to all inquirers today is only available to them through the same 'empirical experience and ... reason' that they have to use to access the discoveries of modern science.

John Polkinghorne defines natural theology as:

the attempt to learn something of God from the exercise of reason and the inspection of the world - in other words, from reflection on general experience. ${ }^{80}$

However, on the one hand, restricting natural theology to the data of 'general experience' excludes much data (originating from the specialised experience of scientists) with which natural theology is traditionally concerned. On the other hand, if we allow natural theology to work with data grounded in the experience of twenty-first century scientists, why not allow natural theology to work with the apostle Paul's first century experience of encountering the resurrected Jesus? 81

William Lane Craig defines natural theology as:

that branch of theology which seeks to provide rational warrant for the proposition that God exists on the basis of argument and evidence independent of authoritative divine revelation. ${ }^{82}$

However, warrant can be provided 'on the basis of argument and evidence inde- 
pendent of an authoritative divine revelation' qua divine revelation without being independent of that revelation qua a source of potential data, as long as that data is established through the use of standard critical methods. That is, since any argument for theism that assumed the revelatory status of a purported divine revelation would be question begging, stipulating that natural theology should proceed 'without recourse to purported special revelation' qua revelation, 'on the basis of argument and evidence independent of authoritative divine revelation' 83 as such, is redundant.

Of course, we are free to define theological disciplines as proceeding on the assumed basis of 'purported special revelation', or not, as we find it convenient. But such choices imply nothing about the legitimacy of apologetic arguments, including the arguments of natural theology. Thus the website of the famous Gifford Lecturers states that: 'Traditionally natural theology is the term used for the attempt to prove the existence of God and divine purpose through observation of nature and the use of human reason.' 84 While this definition leaves the question of purported special revelation to one side - as may be convenient to do in a university course of a limited duration, or a book of limited size - it doesn't try to erect a principled distinction between natural and revealed theology in the manner of Aquinas.

William P. Alston avoids all these problems when he simply defines natural theology as: 'the enterprise of providing support for religious beliefs by starting from premises that neither are nor presuppose any religious beliefs.' 85 In other words, natural theology seeks to offer a non-question-begging defence of theism.

\section{Ramified Natural Theology}

Recent developments in the philosophy of religion show that 'natural theology' shouldn't be understood in too narrow or insular a manner. ${ }^{86}$ For one thing, as Rodney Holder writes: 'the traditional division between natural theology and revealed theology breaks down as soon as we ask why we should believe in a putative revelation and how we can commend our own perceived revelation to others.' ${ }^{\text {'7 }}$ Then again, what Richard Swinburne has called 'ramified natural theology' 88 (i.e. an expanded, more varied natural theology ${ }^{89}$ ) highlights the fact that so-called 'Christian evidences' (e.g. the argument for Jesus' resurrection ${ }^{90}$, the 'trilemma' argument for the deity of Jesus ${ }^{91}$, arguments about fulfilled Biblical prophe$\mathrm{cy}^{92}$, etc.) don't merely round out the classical case for theism with reasons to believe in a specifically Christian God, but can actually do double-work as argument for God in their own right. ${ }^{93}$

Such arguments don't appeal to special revelation qua special revelation, but they often make non-question-begging appeals to evidence relating to purported acts of special revelation, including evidence contained within the historical documents that Christians call Scripture, as well as evidence outside of Scripture. As Hugh G. Gauch Jr. writes: 'For natural theology's purposes, the Bible is read as historical evidence rather than authoritative scripture ...'94

For example, in the course of arguing for the resurrection of Jesus, an apologist may appeal to the historical datum of the creedal material quoted by the apostle Paul in 1 Corinthians 15 , as well as to archaeological evidence showing that it was possible for a crucified man to receive a decent burial. ${ }^{95}$ As Robert A. Larmer observes: 
Traditionally, it has been assumed that natural theology must eschew consideration of special revelation from God and consider only data that is available to unaided reason. This, however, is to ignore the fact that a purported revelation may include content that is empirically verifiable and thus within the purview of natural theology. Miracles are publicly observable events that cry out for an explanation. One need not come to such events already accepting the interpretation placed on them by religious believers. The Bible can be read as historical evidence rather than authoritative Scripture - but neither is one prohibited from considering whether that interpretation does indeed provide the best understanding of the events. This opens up the possibility that someone who initially does not accept theism might at once accept both the claim of God's existence and the claim of God's selfdisclosure. ${ }^{96}$

This means that natural theology is not restricted to the bare theism (or even deism) of what Pascal famously called 'the God of the Philosophers'.

\section{The Breadth of Contemporary Natural Theology}

Twenty-first century natural theology has rediscovered an emphasis upon the intuitive or 'natural' nature of belief in God'7 in dialogue with what we might call 'epistemologies of trust' (e.g. Richard Swinburne's defence of the principles of credulity and testimony, Alvin Plantinga's 'reformed' account of warrant and properly basic beliefs ${ }^{98}$ and/or Michael Huemer's phenomenal conservatism ${ }^{99}$ ). These epistemologies of trust, together with the sheer breadth of arguments offered within contemporary natural theology, 100 helps us avoid focusing too narrowly upon the 'classical' arguments for God discussed by ancient pagans and/or medieval thinkers (i.e. cosmological, teleological, axiological and ontological arguments),101 although these families of argument have all been ably defended by contemporary scholars. ${ }^{102}$

The breadth of contemporary natural theology is demonstrated by the following half-dozen (or so) exemplars:

- Richard Swinburne's The Existence of God (Clarendon, 1979/2004) defended theistic arguments from the beauty of the natural world and from a philosophical anthropology that includes libertarian free will, conscious thoughts, sensations and desires, the conscious acquisition of warranted true beliefs and various types of religious experience (themes that have been explored in a plethora of more recent publications). 103

- Peter Kreeft and Ronald K. Tacelli sketch nearly 'Twenty Arguments For God's Existence'104 (they actually give nineteen arguments for God's existence plus Pascal's wager argument for belief in God) in their entry level Handbook of Christian Apologetics (IVP, 1994).

- In Defense of Natural Theology: A Post-Humean Assessment (James F. Sennett and Douglas Groothuis ed.'s. IVP Academic, 2005) contains essays defending the project of natural theology from the influential but overrated critiques of David Hume, including defences of nine theistic arguments.

- The Blackwell Companion to Natural Theology (ed. William Lane Craig and J.P. Moreland. Wiley-Blackwell, 2009), contains substantial essays defending nine theistic arguments. 
- The Naturalness of Belief: New Essays on Theism's Rationality (ed. Paul Copan and Charles Taliaferro. Lexington, 2018), offers a wide ranging collection of papers defending theism in light of the phenomena of consciousness, intentionality, beauty, human dignity, free will, rationality and knowledge; as well as looking at common-sensical, existential, psychologi$\mathrm{cal}$, and cultural reasons for theistic belief, in addition to insights from the cognitive science of religion.

- Alvin Plantinga's famous 1986 paper on 'Two Dozen (or so) Arguments for God'105 spawned an academic conference at Baylor University in 2014106 and a subsequent book - The Plantinga Project: Two Dozen (Or So) Arguments For God (ed. Jerry L. Walls and Trent Dougherty. Oxford University Press, 2018) - highlighting 29 theistic arguments, including lesser known arguments such as the argument from desire ${ }^{107}$, play, simplicity, etc.

It bears noting that although philosophical anthropology, philosophical aesthetics and so forth are not the ultimate object of natural theology, since theistic arguments can be mounted that try to make explicit relationships between certain conclusions in these different philosophical disciplines and God's existence, these different subjects are inevitably drawn into the task of elaborating a synoptic Christian worldview through the project of natural theology.

\section{A Brief History of the Natural Sciences in Relation to Natural Theology}

The founding assumption of Western medieval universities was that every academic discipline could be philosophically integrated into a coherent, synoptic worldview provided by Christian theology. Due to the secularizing impetus of the Enlightenment, natural philosophy became detached from theology. In the Victorian era 'natural philosophy' became known as 'science'. In the twentieth century, under the influence of logical positivism, 'science' came to be defined as a search for the best understanding of the natural world consistent with a naturalistic worldview. This supposedly neutral 'methodological naturalism' was turned into a de facto metaphysical naturalism via the condemnation of any dissenting understanding of science as 'pseudo-science'. In recent decades, these philosophical strictures have begun to loosen. ${ }^{108}$ As Garrett J. DeWeese \& J.P. Moreland report: 'The inadequacy of methodological naturalism [is now] widely acknowledged by philosophers of science, even among those who are atheists ...' ${ }^{109}$ For example, atheist philosopher of science Bradley Monton rejects methodological naturalism because it stands in tension with seeing science as a search for the truth:

If science really is permanently
committed to methodological natu-
ralism - the philosophical position
that restricts all explanations in sci-
ence to naturalistic explanations -
it follows that the aim of science is
not generating true theories. In-
stead, the aim of science would be
something like: generating the best
theories that can be formulated
subject to the restriction that the
theories are naturalistic. 110

However one sees the relationship between science and metaphysics, it is obvious that the scientific study of the very large (cosmology) and the very small (e.g. molecular biology) has uncovered a wealth of data that gives support to key premises in various arguments for theism. 
As Rodney Holder comments: 'modern cosmology ... has provided a new impetus to natural theology, reviving traditional arguments but expressing them in new ways.' 111 In the first place, discoveries since the 1960's have overturned the ancient pagan assumption that the cosmos exists without a beginning, thereby rejuvenating the discussion of Kalamtype cosmological arguments.112 Moreover, scientists have uncovered a life-permitting 'fine tuning' at the cosmic ${ }^{113}$ (as well as the planetary114) levels of reality that has rejuvenated the discussion about design in both cosmology and natural theology.

Concurrently, discoveries in biology, including the complex information processing systems and intricate molecular machinery within cells, have rejuvenated discussion about design in both the biological sciences and natural theology. ${ }^{115}$

These scientific discoveries, coinciding with a growing disquiet amongst philosophers of science with attempts to define science as methodologically naturalistic ${ }^{116}$, have led to a discussion of the legitimacy of 'theistic science' (a return to natural philosophy open to indirectly testable theistic hypotheses), 117 as well as the birth of the controversial scientific theory of 'Intelligent Design', a scientific theory that provides material of obvious interest to natural theology. Intelligent Design Theory limits itself to making inferences to design whilst heeding David Hume's point that one cannot thereby infer much about the nature of the designer or designers beyond those qualities necessary to account for the design that has been observed. 118

Scientific contributions to natural theology are not limited to the natural sciences. For example, although it's a relatively young field of study, archaeology has yiel- ded a wealth of data that should be taken into account by the search for the historical Jesus (and thus by ramified natural theology). For example, archaeologists and other scientists have recently uncovered data relevant to discussions about the historical existence of Jesus, the date from which people believed that Jesus was divine, Jesus's crucifixion and burial, etc. ${ }^{119}$ Then again, social sciences have contributed to discussions about the reliability of oral tradition in the ancient near east. 120 Recent decades have also seen various attempts to investigate prayer for healing within the experimental scientific framework. ${ }^{121}$ Hence Christian philosophy and/or apologetics needs to cast its net beyond the waters of the natural sciences if these disciplines are to live up to the synoptic vision of the Christian university.

\section{Some Advice on Apologetics and Natural Theology in an Age of Science}

Natural theology and ramified natural theology are sub-disciplines within both Christian apologetics and the philosophy of religion. To be a 'philosopher' means to be 'a lover of wisdom'. As such, a philosopher is dedicated to the wise pursuit and dissemination of true answers to significant questions through the practice of good intellectual habits, 'speaking the truth in love' (Ephesians 4:15).122 Whether or not one is a professional philosopher, one's philosophical worldview $^{123}$ forms the foundation of one's way of life, that is, one's spirituality. ${ }^{124}$ That is to say, the contents and intellectual habits of our minds, coupled with the choices, commitments and attitudes of our hearts, issue in behaviour that characterizes (and re-enforces) our spirituality 
or 'way of life'. Thus, philosophy is an integral component of any spirituality, including Christian spirituality. 125

Christian spirituality is a Christ-centred way of life, a Christ-centred way of relating to reality via one's head, heart and hands. ${ }^{126}$ By drawing upon a range of disciplines, including natural theology, Christian apologetics aims to enable people to be persuaded that a Christ-centred spirituality is a beautiful, good and reasonable commitment. It is the art of persuasively advocating Christian spirituality, through the responsible use of rhetoric, as being objectively beautiful, good and true/reasonable.127 This being so, Christians should approach natural theology as a more than merely 'academic' pursuit, for as Paul Copan writes:

philosophy should be an act of worship ... when we undertake philosophy in Christ's name, our desk or reading chair becomes an altar, yielding 'a fragrant aroma, an acceptable sacrifice, well-pleasing to God' (Phil 4:18).128

Apologetic appeals to scientific data, theories and/or methodology pack a strong rhetorical punch, partly because such appeals tap into a culturally accepted epistemology and partly because such appeals can undermine the mistaken belief that Christians are anti-science (especially when such appeals embrace the scientific consensus). However, it's worth bearing in mind that when making appealing to science, apologists need to avoid appearing to endorse scientism. ${ }^{129}$ As McGrath comments:

One of the most important functions of natural theology is to protest against the radically reduced visions of nature that arise from the movement sometimes known as 'scientific imperialism' but now generally as simply 'scientism'. 130
Although we live in a culture that encourages a degree of scientific literacy, apologists should consider how receptive nonspecialist audiences are likely to be to theistic arguments that require them to begin learning complex information about cosmology or molecular biology, etc. By comparison, other theistic arguments function at a more intuitive level, at least at a first pass. ${ }^{131}$ For example, the meta-ethical moral argument begins with moral experiences common to, and thus readily understood by, all properly functioning humans from an early age.132 Likewise, the argument from desire is rooted in common human experience. ${ }^{133}$

Whilst Christians should continue to explore the theological fruitfulness of contemporary scientific cosmology and biology, it's worth bearing in mind both that natural theology can draw upon a broad range of scientific subjects beyond the natural sciences (e.g. archaeology and social science can both contribute to ramified natural theology) and upon a broad range of knowledge beyond the limited grasp of science (e.g. meta-ethics, aesthetics, philosophical anthropology). Indeed, making arguments that begin with mental properties such as intentionality, or with moral or aesthetic facts, helps make the point that empirical science isn't the self-justifying golden path to everything that can be known hoped for by the logical positivists. 134

I would encourage Christians to give a higher priority to defending the doctrine of creation (focusing upon the creedal claim that God is the ultimate causer and intender, as well as sustainer, of the cosmos) ${ }^{135}$ than to arguing for any particular model of creation (focusing upon differing interpretations of scriptural creation texts and how they can be best integrated into a synoptic Christian worldview).136 
Concerning the quest for a synoptic model of creation, I agree with Michael J. Murray and Michael Rea that:

for the religious believer, the [resolution of purported] conflicts between science and religion will involve balancing evidence against evidence: the empirical evidence favouring scientific claims against the revelatory evidence favouring theological claims. The Christian [might] conclude that the . . . evidence for an ancient earth seems quite strong, while the evidence for the naturalistic origin of life is, in fact, virtually non-existent. This then needs to be balanced against the evidence of revelation. How clear is it that the Bible teaches that the earth is young, or that God directly intervened in the cosmos to bring about life?137

As Plantinga reminds us:

we can't automatically assume that when there is a conflict between science and our grasp of the teach- ing of Scripture, it is science that is wrong and must give way. But the same holds vice versa; when there is a conflict between our grasp of the teaching of Scripture and current science, we can't assume that it is our interpretation of Scripture that is at fault. It could be that, but it doesn't have to be; it could be because of some mistake or flaw in current science. ${ }^{138}$

Science and theology (including natural theology) are fallible human projects. Wisdom enjoins that we do our best to follow the available evidence where it appears to lead, yet without falling into undue dogmatism. 139

Finally, I'd encourage Christians to engage with the many challenges to and opportunities for apologetics provided by contemporary popular culture, challenges and opportunities that are often focused around science or found within science fiction. 140

\footnotetext{
Notes

1 John Wesley, ‘An Address to the Clergy' http://wesley.nnu.edu/john_wesley/10clergy.htm.

2 As John M. Frame observes: 'For some this belief may be an immediate response to the world around them. For others it may be the result of an argument.' - Steven B. Cowen, ed. Five Views on Apologetics (Grand Rapids, Michigan: Zondervan, 2000), 80. See: Brian K. Morley, Mapping Apologetics: Comparing Contemporary Approaches (Downers Grove, IL: IVP, 2015), 231-232 \& 364.

3 See: Clinton E. Arnold, Acts (Grand Rapids, Michigan: Zondervan, 2002), 134-136. See also: Lars Dahle, 'Acts 17:16-34: An Apologetic Model Then and Now?' Tyndale Bulletin 53.2 (2002) 313-316, https://legacy.tyndalehouse.com/tynbul/Library/TynBull_2002_53_2_09_Dahle_Acts17Apologetic.pdf.

4 Norman L. Geisler, Philosophy of Religion (Grand Rapids, MI: Zondervan, 1974), 208.

5 Alister McGrath, Enriching our Vision of Reality: Theology and the Natural Sciences in Dialogue (West Conshohocken, PA: Templeton Press, 2017), 169.

6 McGrath, Enriching our Vision of Reality, 169.

7 McGrath, Enriching our Vision of Reality, 170.

8 McGrath, Enriching our Vision of Reality, 170.

9 McGrath, Enriching our Vision of Reality, 171.

10 McGrath, Enriching our Vision of Reality, 66.

11 McGrath, Enriching our Vision of Reality, 67.

12 Stephen T. Davis, God, Reason and Theistic Proofs (Edinburugh: Edinburugh University Press, 1997), 13.

13 Alvin Plantinga, 'Two dozen (or so) arguments for God' https://appearedtoblogly.files.wordpress.com/ 2011/05/plantinga-alvin-22two-dozen-or-so-theistic-arguments221.pdf.

14 For discussion of what makes an argument a good argument, see: William Lane Craig and Joseph E. Gorra, Reasonable Response (Chicago, IL: Moody, 2013); Stephen T. Davis, God, Reason and Theistic Proofs (Edinburugh: Edinburugh University Press, 1997); Alvin Plantinga, 'Two dozen (or so) arguments for God' https://appearedtoblogly.files.wordpress.com/2011/05/plantinga-alvin-22two-dozen-or-so-theisticarguments221.pdf.
} 
15 F.C. Copleston in John Hick, ed. The Existence of God (New York: Macmillan, 1964), 178, 180.

16 See: John Hick, ed. The Existence of God (New York: Macmillan, 1964), 120-136.

17 See: John Hick, ed. The Existence of God (New York: Macmillan, 1964), 99-103; Peter S. Williams, A Faithful Guide to Philosophy: A Christian Introduction to the Love of Wisdom (Eugene, Oregon: Wipf and Stock, 2019), chapter six.

18 See: Blaise Pascal, Honor Levi, trans., Pensées and other writings (Oxford: Oxford University Press, 1995), 52.

19 Thomas Aquinas's fifth way from Summa Theologica in Hick, ed. The Existence of God, 85.

20 See: Richard Swinburne, 'The Justification of Theism' www.leaderu.com/truth/3truth09.html; Richard Swinburne, 'Evidence for God' (1986) http://christianevidence.org/docs/booklets/evidence_for_god.pdf; Richard Swinburne, The Existence of God, second edition (Cambridge: Clarendon Press, 2004); The Resurrection of God Incarnate (Cambridge: Clarendon Press, 2003). See also: Rodney Holder, Ramified Natural Theology in Science and Religion (London: Routledge Science and Religion Series, 2020).

21 See: David Sedley, Creationism And Its Critics In Antiquity (California: University of California Press, 2007).

22 See: Hugh Montifiore, The Probability of God (London: SCM, 1985), chapter one.

23 Peter May, 'Karl Barth and Natural Theology?'

www.bethinking.org/is-christianity-true/karl-barth-and-natural-theology. As Wyatt Houtz writes: 'Barth's protest against Natural Revelation was also a protest against the Nazi claim to be a revelation of God.' 'Karl Barth's No! to Natural Theology: Secular Parables of the Kingdom' https://postbarthian.com/2016/07/22/karl-barths-no-natural-theology-secular-parables-kingdom/. See also: James Barr, 'Natural Theology in This Century: Concepts and Approaches', www.giffordlectures.org/books/biblical-faith-and-natural-theology/1-natural-theology-century-concepts-andapproaches.; Rodney Holder, The Heavens Declare: Natural Theology and the Legacy of Karl Barth (West Conshohocken, PA: Templeton Press, 2012).

24 May, 'Karl Barth and Natural Theology?'

25 May, 'Karl Barth and Natural Theology?'

26 See: Alister McGrath, Enriching our Vision of Reality (West Conshohocken, PA: Templeton Press, 2017), 56-58. See also William Lane Craig, 'Classical Apologetics' in Steven B. Cowen, ed. Five Views On Christian Apologetics (Grand Rapids, MI: Zondervan, 2000), 39-43.

27 For example: 'Disillusioned with Dawkins: My Journey from Atheism to Christianity: Peter Byrom' www.solas-cpc.org/disillusioned-with-dawkins-my-journey-from-atheism-to-christianity-peter-byrom/.

28 Kelly James Clark, Philosophers Who Believe: The Spiritual Journeys Of 11 Leading Thinkers (Downers Grove, Illinois: IVP, 1993), Introduction

www.calvin.edu/academic/philosophy/writings/pwbintro.htm.

29 Clark, Philosophers Who Believe, Introduction.

30 Clark, Philosophers Who Believe, Introduction.

31 See: Lewis Carroll, 'Jabberwocky', https://interestingliterature.com/2016/01/22/a-short-analysis-of-jabberwocky-by-lewis-carroll/.

32 Wikipedia, 'A.J. Ayer' http://en.wikipedia.org/wiki/A._J._Ayer.

33 A.J. Ayer, Language, Truth and Logic, 2nd edition (London: Victor Gollancz, 1946), 115.

34 Ayer, Language, Truth and Logic, 175.

35 A.J. Ayer, The Central Questions of Philosophy (London: Penguin, 1973), 118-119. cf. C.S. Lewis, The Abolition of Man (Grand Rapids, MI: Zondervan, 2001).

36 F.C Copleston, Contemporary Philosophy: Studies of Logical Positivism and Existentialism (London: Burns \& Oates, 1957), 9.

37 Hilary Spurling, 'The Wikedest Man in Oxford' www.nytimes.com/books/00/12/24/reviews/001224.24spurlit.html.

38 Spurling, 'The Wickedest Man in Oxford'.

39 E.L. Mascall, He Who Is (New York: Longmans, Green and Co., 1954), Preface, xi.

40 Copleston, Contemporary Philosophy, 9.

41 Bruce R. Reichenbach, The Cosmological Argument: A Reassessment (Springfield, Illinois: Charles C. Thomas, 1972), ix.

42 Victor Reppert, C. S. Lewis's Dangerous Idea (Downers Grove, IL: IVP, 2003), 20.

43 F.C. Copleston, 'Logical Positivism-A Debate' in A Modern Introduction to Philosophy, Paul Edwards and Arthur Pap, ed.'s. (New York: The Free Press, 1965), 756.

44 John Hick, 'Theology and Verification' in Basil Mitchell, ed. The Philosophy of Religion (Oxford: Oxford University Press, 1971), 69. 
45 'According to Newton's law of gravitation, the more distant a star is from the centre of a spiral galaxy, the lower its orbiting velocity. However, observations showed that even stars in the far periphery of a galaxy orbited at nearly the same speed as those closer to the centre. To our eyes, galactic mass appears concentrated towards the centre and diminishes towards the periphery. And yet the stars at the periphery move as if they are embedded in much greater mass ... The unseen matter, by inference, must be a major component of galaxies. This came to be known as 'dark matter.' This non-luminous matter has not been confirmed by observations at any electromagnetic wavelength and constitutes at least 90 percent of the universe.' Singapore Science Centre www.science.edu.sg/ssc/detailed.jsp? artid=4191 andtype $=6 \&$ root $=6 \&$ parent $=6 \&$ cat $=65$.

46 See: Douglas Scott and Martin White, 'Cosmic Microwave Background Radiation' www.astro.ubc.ca/people/scott/cmb_intro.html.

47 Lloyd Eby, 'Viewpoint: What is Science? Part I', World Peace Herald (December 16th, 2005) www.wpherald.com/storyview.php?StoryID=20051216-041328-8321r.

48 Hick, 'Theology and Verification', 71.

49 William Lane Craig, Philosophy of Religion: A Reader and Guide (Edinburgh: Edinburgh University Press, 2002), 1.

50 Alvin Plantinga, God and Other Minds (Ithaca, New York: Cornell University Press, 1967), 271.

51 See: Alvin Plantinga, 'The Ontological Argument'

www.lastseminary.com/ontological-argument/Plantinga \%20-\%20The\%20Ontological\%20Argument.pdf.

See also: YouTube Playlist, 'The Ontological Argument for God'

www.youtube.com/playlist?list=PLQhh3qcwVEWjE7hqAz3D6jp7MWjChVYKn; Peter S. Williams and Peter Millican, 'Debating the Ontological Argument'

https://unbelievable.podbean.com/e/debating-the-ontological-argument-peter-s-williams-peter-millican/; Peter S. Williams, 'A Brief Introduction to and Defence of the Modern Ontological Argument' https://theofilos.no/wp-content/uploads/2019/09/3d_Forum_Williams_A-Brief-Introduction-to-and-Defenceof-the-Modern-Ontological-Argument.pdf; Peter S. Williams, A Faithful Guide to Philosophy: A Christian Introduction to the Love of Wisdom (Eugene, Oregon: Wipf and Stock, 2019).

52 Basil Mitchell, 'Reflections on C.S. Lewis, Apologetics, And the Moral Tradition: Basil Mitchell in Conversation with Andrew Walker' in Andrew Walker and James Patrick, ed.'s. Rumours of Heaven: Essays in Celebration of C.S. Lewis (Guildford: Eagle, 1998), 19.

53 R. Douglas Geivett, 'The evidential Value of Religious Experience' in Paul Copan and Paul K. Moser, ed.'s. The Rationality of Theism (London: Routledge, 2003), 175.

54 William P. Alston, 'Religious Language and Verificationism', Copan and Moser, ed.'s. The Rationality of Theism, 21.

55 Ayer, The Central Questions of Philosophy, 34.

56 Keith Ward, God: A Guide for the Perplexed (Oxford: OneWorld, 2002), 184.

57 Clark, Philosophers Who Believe, 11-12.

58 William Lane Craig, 'Advice to Christian Apologists'

www.baptistpastors.org.au/Mosaic/Spring_Summer_2002/lane_advice_to_apologists.htm.

59 Ronald H. Nash, Faith and Reason (Grand Rapids, Michigan: Zondervan, 1988), 53.

60 Roger Scruton, An Intelligent Person's Guide To Philosophy (London: Duckworth, 1997), 18.

61 Ayer, The Central Questions of Philosophy, 22-34.

62 A.J. Ayer, The Listener, 2 March 1978.

63 A.J. Ayer, quoted by Keith Ward, The Turn of the Tide (London: BBC Publications, 1986), 59.

64 A.J. Ayer in Roy Abraham Vargese ed., Great Thinkers on Great Questions (Oxford: OneWorld, 1998), 49.

65 William Lane Craig, Philosophy of Religion: A Reader and Guide (Edinburgh: Edinburgh University Press, 2001), 1.

66 'Modernizing the Case for God', Time Magazine, 7 April 1980, 65-66.

67 Tyler Burge, 'Philosophy of Language and Mind' Philosophical Review 101 (1992), 49.

68 James Brent, 'Natural Theology' in Internet Encyclopedia of Philosophy, www.iep.utm.edu/theo-nat/\#H4.

69 James Swindal, 'Faith and Reason' in Internet Encyclopedia of Philosophy, www.iep.utm.edu/faith-re/\#SH4e.

70 Thomas Aquinas, Summa Contra Gentiles, https://dhspriory.org/thomas/english/ContraGentiles1.htm\#4.

71 Aquinas, Summa Contra Gentiles, https://dhspriory.org/thomas/english/ContraGentiles1.htm\#6, my italics.

72 Shawn Floyd, 'Aquinas: Philosophical Theology' in Internet Encyclopedia of Philosophy, www.iep.utm.edu/aq-ph-th/\#SH3c.

73 Aquinas, Summa Contra Gentiles, https://dhspriory.org/thomas/english/ContraGentiles1.htm\#3. 
74 See: Stephen T. Davies, 'A Somewhat Playful Proof of the Social Trinity in Five Easy Steps', Philosophia Christi, Series 2, Vol.1, No.2, 103; J.P. Moreland and William Lane Craig, Philosophical Foundations for a Christian Worldview (Downers Grove, IL: IVP, 2003), 594-595.

75 See: Richard of St Victor, On the Trinity (Eugene, Oregon: Cascade, 2011); Richard Swinburne, The Christian God (Oxford: Oxford University Press, 1995); Peter S. Williams, 'Understanding the Trinity' www.bethinking.org/god/understanding-the-trinity.

76 Hugh G. Gauch Jr., 'Recent Transitions in Natural Theology: The Emergence of a Bolder Paradigm ( IBRI Research Reports Book 58).' www.amazon.co.uk/Recent-Transitions-Natural-Theology-Emergence-ebook/dp/B009EIKNMY.

77 See: Dallas Willard, 'Language, Being, God, and the Three Stages of Theistic Evidence' www.dwillard.org/articles/individual/language-being-god-and-the-three-stages-of-theistic-evidence; Peter S. Williams, 'A Universe From Someone - Against Lawrence Krauss' (2012) www.bethinking.org/is-there-a-creator/a-universe-from-someone-against-lawrence-krauss.

78 James F. Sennett and Douglas Groothuis, 'Introduction' in James F. Sennett and Douglas Groothuis, ed.'s. In Defence of Natural Theology: A Post-Humean Assessment (Downers Grove, IL: IVP Academic, 2005), 10.

79 Scott MacDonald, 'Natural Theology' Routledge Encyclopedia of Philosophy www.rep.routledge.com/articles/thematic/natural-theology/v-1.

80 John Polkinghorne, 'Where Is Natural Theology Today?' Science and Christian Belief 18 (2006): 169.

81 See: Peter May, 'The Resurrection of Jesus and the Witness of Paul' www.bethinking.org/did-jesus-rise-from-the-dead/the-resurrection-of-jesus-and-the-witness-of-paul; Peter S. Williams, Getting at Jesus (Eugene, Oregon: Wipf and Stock, 2019).

82 William Lane Craig, ed. Philosophy of Religion: A Reader and Guide, 'Natural Theology: Introduction' (New Jersey: Rutgers University Press, 2002), 69.

83 Craig, ed. Philosophy of Religion, 69. Likewise, Colin Brown defined natural theology as 'the attempt to attain an understanding of God and his relationship with the universe by means of rational reflection, without an appeal to special revelation.' (Sinclair B. Ferguson and David F. Wright, ed.'s. New Dictionary of Theology (Leicester: IVP, 1988), 452.

84 www.giffordlectures.org/overview/natural-theology.

85 William P. Alston, quoted by Rodney Holder, Ramified Natural Theology in Science and Religion (London: Routledge Science and Religion Series) (Kindle Android version, 2020), 19.

86 See: Robert A. Larmer, 'The 'Argument From Miracle': An Example of Ramified Natural Theology' www.epsociety.org/userfiles/art-Larmer\%20(ArgumentFromMiracle-ExampleOfRamified).pdf; Angus Menuge and Charles Taliaferro 'Introduction to a Special Issue of Philosophia Christi on Ramified Natural Theology' www.epsociety.org/library/articles.asp?pid=195; Angus Menuge, 'Ramified Personalized Natural Theology: A Third Way?' www.epsociety.org/userfiles/art-Menuge\%20(Ramified\%20Personalized\%20Natural\%20Theology).pdf.

87 Rodney Holder, Ramified Natural Theology in Science and Religion (London: Routledge Science and Religion Series) (Kindle Android version, 2020),78.

88 Richard Swinburne, 'Natural Theology, Its "Dwindling Probabilities" and "Lack of Rapport"' Faith and Philosophy 21(4): 533-546 (2004).

89 To 'ramify' means 'to spread and develop many parts or branches.' Accordingly, 'Ramified' means 'having many different parts or branches' https://dictionary.cambridge.org/dictionary/english/ramify.

90 See: Craig Blomberg and Carl Stecher with contributions by Richard Carrier and Peter S. Williams, Resurrection: Faith or Fact? A Scholars' Debate Between a Skeptic and a Christian (Durham, North Carolina: Pitchstone, 2019); Peter S. Williams, 'Resurrection: Faith or Fact? Miracle Not Required?' https://theofilos.no/wp-content/uploads/2020/03/Theofilos-vol.-11-nr.-2-2019-Forum-3-Arkiv.pdf; Peter S. Williams, Getting at Jesus: A Comprehensive Critique of Neo-Atheist Nonsense About the Jesus of History (Eugene, Oregon: Wipf \& Stock, 2019).

91 See: Williams, Getting at Jesus: A Comprehensive Critique of Neo-Atheist Nonsense About the Jesus of History (Eugene, Oregon: Wipf \& Stock, 2019).

92 See: YouTube Playlist, 'Biblical Prophecy'

www.youtube.com/playlist?list=PLQhh3qcwVEWgq_Hba52LXvmcUHR4T01oa; Robert C. Newman, ed. The Evidence of Prophecy: Fulfilled Prediction as a Testimony to the Truth of Christianity (Hatfield, Pennsylvania: IBIR, 1998); Peter S. Williams, Understanding Jesus (Milton Keynes: Paternoster, 2011). 93 See: Angus Menuge and Charles Taliaferro 'Introduction to a Special Issue of Philosophia Christi on Ramified Natural Theology' www.epsociety.org/library/articles.asp?pid=195.

94 Gauch Jr., 'Recent Transitions in Natural Theology'.

95 See: Williams, Getting at Jesus (Eugene, Oregon: Wipf \& Stock, 2019).

96 Robert A. Larmer, 'The “Argument From Miracle”: An Example of Ramified Natural Theology' www.epsociety.org/userfiles/art-Larmer\%20(ArgumentFromMiracle-ExampleOfRamified).pdf. 
97 See: C. Stephen Evans, Natural Signs and Knowledge of God: A New Look at Theistic Arguments (Oxford: Oxford University Press, 2012); Paul Copan and Charles Taliaferro, ed.'s. The Naturalness of Belief: New Essays on Theism's Rationality (London: Lexington, 2018).

98 See: Alvin Plantinga, Knowledge and Christian Belief (Grand Rapids, Michigan: Eerdmans, 2015); Alvin Plantinga Warranted Christian Belief (Oxford: Oxford University Press, 2000). See also: Stephen Wykstra, “"Not Done in a Corner” Revisited: Becoming a More Sensible Evidentialist about Jesus' (2017) https://youtu.be/7Tmngq3ZR1w; Mitch Stoke, A Shot of Faith (to the Head): Be a Confident Believer in an Age of Cranky Atheists (Nashville, Tennessee: Thomas Nelson, 2012).

99 See: CCA, 'Phenomenal Conservatism, Evidentialism, and Religious Epistemology (Dr. Chris Tucker)' https://youtu.be/LgBlLnT3h38; Michael Huemer, 'Compassionate Phenomenal Conservatism' www.academia.edu/4446095/Compassionate_Phenomenal_Conservatism; Luca Moretti, 'phenomenal conservatism' https://core.ac.uk/download/pdf/204175534.pdf.

100 See: YouTube Playlist: 'Natural Theology' YouTube playlist:

www.youtube.com/playlist?list=PLQhh3qcwVEWiDA8QN4h8wLrrbm49fLzPN; YouTube Playlist, 'Debating God' YouTube playlist: www.youtube.com/playlist?list=PLQhh3qcwVEWiY3UmTA iRdj2OW4SBG0y_W.

101 See: David Sedley, Creationism And Its Critics In Antiquity (Berkeley: University of California Press, 2007); Frederick Copleston, A History of Philosophy: Volume 2 - Medieval Philosophy (New York: Continuum, 2003).

102 See: William Lane Craig, 'Five Arguments for God'

http://christianevidence.org/docs/booklets/five_arguments_for_god.pdf; William Lane Craig and J.P.

Moreland, The Blackwell Companion to Natural Theology (Wiley-Blackwell, 2009); J.P. Moreland and William Lane Craig, Philosophical Foundations for a Christian Worldview, second edition (Downers Grove, IL: IVP, 2017); J.P. Moreland, Scaling the Secular City: A Defence of Christianity (Grand Rapids, Michigan: Baker, 1987); James F. Sennett and Douglas Groothuis, ed.'s. In Defence of Natural Theology: A PostHumean Assessment (Downers Grove, IL: IVP, 2005); Peter S. Williams, Outgrowing God? A Beginner's Guide to Richard Dawkins and the God Debate (Eugene, Oregon: Cascade, 2020); Peter S. Williams, A Faithful Guide to Philosophy: A Christian Introduction to the Love of Wisdom (Eugene, Oregon: Wipf and Stock, 2019).

103 See: Gregory Bassham ed. C.S. Lewis's Christian Apologetics: Pro and Con (Leiden: Brill/Rodopi, 2015); Thomas Dubay, The Evidential Power Of Beauty: Science And Theology Meet (San Francisco: Ignatius, 1999); Angus Menuge, Agents Under Fire: Materialism And The Rationality Of Science (Lanham, Maryland: Rowman \& Littlefield, 2004); J.P. Moreland, The Recalcitrant Imago Dei: Human Persons and the Failure of Naturalism (London: SCM, 2009), J.P. Moreland, Consciousness and the Existence of God: A Theistic Argument (London: Routledge, 2008); J.P. Moreland, Scaling the Secular City: A Defence of Christianity (Grand Rapids, Michigan: Baker, 1987); Alvin Plantinga, Where The Conflict Really Lies: Science, Religion, \& Naturalism (Oxford: Oxford University Press, 2011); Victor Reppert, C.S. Lewis's Dangerous Idea: In Defense of the Argument from Reason (Downers Grove, IL: IVP Academic, 2003); Peter S. Williams, A Faithful Guide to Philosophy: A Christian Introduction to the Love of Wisdom (Eugene, Oregon: Wipf and Stock, 2019); Peter S. Williams, 'Intelligent Design, Aesthetics and Design Arguments' www.arn.org/docs/williams/pw_idaestheticsanddesignarguments.htm; Peter S. Williams 'In Defence of Arguments From Desire' www.peterswilliams.com/2016/11/02/in-defence-of-arguments-from-desire/. 104 See: Peter Kreeft and Ronald K. Tacelli, 'Twenty Arguments For God's Existence' www.peterkreeft.com/topics-more/20_arguments-gods-existence.htm.

105 Alvin Plantinga, 'Two dozen (or so) arguments for God' https://appearedtoblogly.files.wordpress.com/ 2011/05/plantinga-alvin-22two-dozen-or-so-theistic-arguments221.pdf.

106 See: Baylor Institute for the Study of Religion, Plantinga Conference 2014, www.youtube.com/playlist?list=PL0JmtbsEea3gcN5eNq-0JXq2qTwDg7L_Q.

107 See: YouTube Playlist: 'The Argument from Desire'

www.youtube.com/playlist?list=PLQhh3qcwVEWj3nK3TBydEVAFRtdqfrpW2; Peter S. Williams, 'A Beginner's Guide to the Theistic Argument from Desire' www.solas-cpc.org/a-beginners-guide-to-the-theistic-argument-from-desire/; Gregory Bassham ed. C.S. Lewis's Christian Apologetics: Pro and Con (Leiden: Brill/Rodopi, 2015), 27-74; Peter S. Williams 'In Defence of Arguments From Desire' www.peterswilliams.com/2016/11/02/in-defence-of-arguments-from-desire/; Joe Puckett Jr. The Apologetics of Joy: A Case for the Existence of God from C.S. Lewis's Argument from Desire (Cambridge: Lutterworth, 2013).

108 See: Peter S. Williams, 'Atheists Against Darwinism: Johnson’s Wedge Breaks Through' http://epsociety.org/library/articles.asp?pid=66; Jonathan Bartlett and Eric Holloway, ed.'s. Naturalism And Its Alternatives In Scientific Methodologies (Broken Arrow, Oklahoma: Blyth Institute Press, 2017); Bruce L. Gordon and William A. Dembski, ed.'s. The Nature of Nature: Examining the Role of Naturalism in Science (Wilmington, DE: ISI Books, 2011); J.P. Moreland, ed. The Creation Hypothesis: Scientific Evidence for an Intelligent Designer (Downers Grove, IL: IVP, 1994); Del Ratzsch, Science \& Its Limits: The Natural Sciences in Christian Perspective, second edition (Downers Grove, IL: IVP, 2000). 
109 Garrett J. DeWeese and J.P. Moreland, Philosophy Made Slightly Less Difficult (Downers Grove, IL: IVP, 2005), 146.

110 Bradley Monton, 'Is Intelligent Design Science? Dissecting the Dover Decision'

http://philsci-archive.pitt.edu/archive/00002592/01/Methodological_Naturalism_Dover_3.doc.

111 Holder, Ramified Natural Theology in Science and Religion, 4.

112 See: Paul Copan and William Lane Craig, ed.'s. The Kalam Cosmological Argument, Volume 2: Scientific Evidence for the Beginning of the Universe (New York: Bloomsbury Studies in Philosophy of Religion, 2019); J.P. Moreland and William Lane Craig, Philosophical Foundations for a Christian Worldview, second edition (Downers Grove, IL: IVP, 2017); Peter S. Williams, A Faithful Guide to Philosophy (Eugene, Oregon: Wipf and Stock, 2019).

113 See: Robin Collins' Fine-Tuning Website, http://home.messiah.edu/ rcollins/Fine-tuning/FT.HTM; Paul Davies, The Goldilocks Enigma (London: Penguin, 2007); J.P. Moreland and William Lane Craig, Philosophical Foundations for a Christian Worldview, second edition (Downers Grove, IL: IVP, 2017); Peter S. Williams, Outgrowing God? A Beginner's Guide to Richard Dawkins and the God Debate (Eugene, Oregon: Cascade, 2020).

114 See: Guillermo Gonzalez and Jay W. Richards, The Privileged Planet: How Our Place In The Cosmos Is Designed For Discovery (Washington, DC: Regnery, 2004).

115 See: William A. Dembski and Jonathan Wells, The Design of Life: Discovering Signs of intelligence in Biological Systems (Foundation for Thought and Ethics, 2008); Chad Meister, Introducing Philosophy of Religion (London: Routledge, 2009). See also: Michael J. Behe, Darwin Devolves: The New Science about DNA That Challenges Evolution (HarperOne, 2019), The Edge of Evolution: The Search for the Limits of Darwinism (New York: Free Press, 2007) \& Darwin's Black Box: The Biochemical Challenge to Evolution, $10^{\text {th }}$ anniversary edition (New York: Free Press, 2006); Matti Leisola and Jonathan Witt, Heretic: One Scientist's Journey from Darwin to Design (Seattle: Discovery Institute, 2018); Robert J. Marks II, William A. Dembski and Winston Ewert, Introduction to Evolutionary Informatics (Singapore: World Scientific, 2017); Stephen C. Meyer, Darwin's Doubt: The Explosive Origin Of Animal Life And The Case For Intelligent Design (New York: HarperOne, 2013) \& Signature In The Cell: DNA And The Evidence For Intelligent Design (New York: HarperOne, 2009); Charles B. Thaxton et al, The Mystery of Life's Origin: The Continuing Controversy (Seattle: Discovery Institute, 2020); Peter S. Williams, 'Intelligent Designs on Science' www.peterswilliams.com/2016/02/09/intelligent-designs-on-science/, 'Atheists Against Darwinism: Johnson's Wedge Breaks Through' http://epsociety.org/library/articles.asp?pid=66, 'The Design Inference from Specified Complexity Defended by Scholars Outside the Intelligent Design Movement: A Critical Review' Philosophia Christi (Vol. 9, Issue 2, 2007)

www.discovery.org/scripts/viewDB/filesDB-download.php?command=download\&id=1491; Outgrowing God? A Beginners' Guide to Richard Dawkins and the God Debate (Eugene, Oregon: Cascade, 2020); A Faithful Guide to Philosophy: A Christian Introduction to the Love of Wisdom (Eugene, Oregon: Wipf and Stock, 2019) \& I Wish I Could Believe In Meaning: A Response To Nibilism (Southampton: Damaris, 2004).

116 See: Del Ratzsch, Science \& Its Limits: The Natural Sciences in Christian Perspective, second edition (Downers Grove, IL: IVP, 2000).

117 See: J.P. Moreland ed., The Creation Hypothesis: Scientific Evidence for an Intelligent Designer (Downers Grove, IL: IVP, 1994); Fuzale Rana and Hugh Ross, Origins of Life: Biblical and Evolutionary Models Face Off (Covina, CA: RTB Press, 2014).

118 See: YouTube Playlist, 'Debating Intelligent Design Theory'

www.youtube.com/playlist?list=PLQhh3qcwVEWhO4mPNzA-K41C7VfvSvkQW; William A. Dembski \& Jonathan Wells, The Design of Life: Discovering Signs of intelligence in Biological Systems (Richardson, Texas: Foundation for Thought and Ethics, 2008); Bruce L. Gordon and William A. Dembski, ed.'s. The Nature of Nature: Examining the Role of Naturalism in Science (Wilmington, DE: ISI Books, 2011); Bradley Monton, Seeking God in Science: An Atheist Defends Intelligent Design Theory (Peterborough, Canada: Broadview Press, 2009); Peter S. Williams, 'The Design Inference from Specified Complexity Defended by Scholars Outside the Intelligent Design Movement: A Critical Review' Philosophia Christi (Vol. 9, Issue 2, 2007) www.discovery.org/scripts/viewDB/filesDB-download.php? command=download\&id=1491; 'Atheists Against Darwinism: Johnson's Wedge Breaks Through' http://epsociety.org/library/articles.asp?pid=66; 'Intelligent Designs on Science' (2006) www.peterswilliams.com/2016/02/09/intelligent-designs-on-science/

and 'Design and the Humean Touchstone' www.arn.org/docs/williams/pw_humeantouchstone.htm.

119 See: Craig A. Evans, Jesus and the Remains of His Day: Studies in Jesus and the Evidence of Material Culture (Peabody, Massachusetts: Henderickson, 2015); Peter S. Williams, 'Archaeological Evidence and Jesus' https://youtu.be/ZaGlKZqED1k; Peter S. Williams, 'Archaeological Evidence and Jesus' http://podcast.peterswilliams.com/e/elf-2020-archaeological-evidence-and-jesus/, Peter S. Williams, 'Defending Early High Christology with Archaeology and New Testament Letters' https://youtu.be/vUha7-4Puy8; Peter S. Williams, 'Digging for Evidence: Archaeology and the Historical Reliability of the New Testament' Christian Evidence Society (2016) http://christianevidence.org/docs/booklets/digging_for_evidence.pdf \& Peter S. 
Williams, Getting at Jesus: A Comprehensive Critique of Neo-Atheist Nonsense About the Jesus of History (Eugene, Oregon: Wipf and Stock, 2019).

120 See: Paul Rhodes Eddy and Gregory A. Boyd, The Jesus Legend: A Case for the Historical Reliability of the Synoptic Jesus Tradition (Grand Rapids, Michigan: Baker Academic, 2007).

121 See: Candy Gunther Brown, Testing Prayer (Cambridge, Massachusetts: Harvard University Press, 2012).

122 See: Peter S. Williams, A Faithful Guide to Philosophy (Eugene, Oregon: Wipf and Stock, 2019).

123 See: YouTube Playlist, 'Understanding Worldviews'

www.youtube.com/playlist?list=PLQhh3qcwVEWhCn7rqlW7UsvFNRjQ9wxoH;

James W. Sire, The Universe Next Door: A Basic Worldview Catalogue, fifth edition (IVP, 2009).

124 See: Peter S. Williams, 'Apologetics in 3D - "Input” at Trondheim Frikirke' (2018)

http://podcast.peterswilliams.com/e/apologetics-in-3d-input-at-trondheim-frikirke/ \& 'Apologetics in 3D:

Persuading Across Spiritualities With the Apostle Paul', Theofilos (2012:1)

www.bethinking.org/apologetics/apologetics-in-3d.

125 See: YouTube Playlist, 'Discipleship \& Spiritual Formation'

www.youtube.com/playlist?list=PLQhh3qcwVEWhGSK1x6H3qeqzefB8hmvvM; André Comte-Sponville, The Book Of Atheist Spirituality: An Elegant Argument For Spirituality Without God (London: Bantam, 2007); Philip Sheldrake, Spirituality: A Very Short Introduction (Oxford: Oxford University Press, 2012); Peter S. Williams, 'Apologetics in 3D' https://youtu.be/hiUHeaEaPLA; Peter S. Williams, 'Apologetics in 3D - "Input" at Trondheim Frikirke' (2018)

http://podcast.peterswilliams.com/e/apologetics-in-3d-input-at-trondheim-frikirke/; 'Apologetics in 3D:

Persuading Across Spiritualities With the Apostle Paul', Theofilos (2012:1)

www.bethinking.org/apologetics/apologetics-in-3d \& Understanding Jesus: Five Ways to Spiritual

Enlightenment (Milton Keynes: Paternoster, 2011).

126 See: Peter S. Williams, 'Discipleship in 3D: Change for head, heart and hands'

https://youtu.be/QTyEo0JgIBI; Peter S. Williams, 'Apologetics in 3D: Persuading across Spiritualities with the Apostle Paul', Theofilos 2012:1, 3-24, www.bethinking.org/apologetics/apologetics-in-3d.

127 See: Peter S. Williams, 'Apologetics in 3D' https://youtu.be/hiUHeaEaPLA; Peter S. Williams, 'Apologetics in 3D - "Input" at Trondheim Frikirke' (2018)

http://podcast.peterswilliams.com/e/apologetics-in-3d-input-at-trondheim-frikirke/; Peter S. Williams,

'The Apologetics of Cultural Re-Enchantment in 3D: Makoto Fujimura's Culture Care \& Paul M. Gould's

Cultural Apologetics' Theofilos 2019/1 (June / July), 79-88, https://theofilos.no/wp-content/uploads/

2020/03/3e_Forum_Williams_The-Apologetics-of-Cultural-Re-Enchantment-in-3D.pdf; Peter S. Williams,

'Apologetics in 3D: Persuading across Spiritualities with the Apostle Paul' Theofilos (2012:1), 3-24,

www.bethinking.org/what-is-apologetics/advanced/apologetics-in-3d.htm.

128 Paul Copan, A Little Book for New Philosophers (Downers Grove, Illinois: IVP Academic, 2016), 119-120.

129 See: Peter S. Williams, YouTube Playlist: 'Scientism'

www.youtube.com/playlist?list=PLQhh3qcwVEWiIgrCwkM8Y-RoqU1TmYK8R.

130 McGrath, Enriching our Vision of Reality, 174.

131 See: Peter S. Williams, 'Arguing for God' (August 2020)

http://podcast.peterswilliams.com/e/arguing-for-god/.

132 See: Peter S. Williams, 'Can Moral Objectivism Do Without God?’ Theofilos (2011)

www.bethinking.org/morality/can-moral-objectivism-do-without-god; Peter S. Williams, Outgrowing God?

A Beginner's Guide to Richard Dawkins and the God Debate (Eugene, Oregon: Cascade, 2020), chapter four; A Faithful Guide to Philosophy (Eugene, Oregon: Wipf and Stock, 2019), chapter 8; Robert K. Garcia and Nathan L. King, Is Goodness without God Good Enough? A Debate On Faith, Secularism, And Ethics (Lanham, Maryland: Rowman \& Littlefield, 2009).

133 See: YouTube Playlist: 'The Argument from Desire'

www.youtube.com/playlist?list=PLQhh3qcwVEWj3nK3TBydEVAFRtdqfrpW2; Peter S. Williams, 'A

Beginner's Guide to the Theistic Argument from Desire'

www.solas-cpc.org/a-beginners-guide-to-the-theistic-argument-from-desire/; 'C.S. Lewis as a Central Figure in Formulating the Theistic Argument from Desire', Linguaculture (Volume 10, 2019:2),

http://journal.linguaculture.ro/images/2019-2/Linguaculture\%202_2019_11_Peter\%20S\%20Williams.pdf;

Gregory Bassham ed. C.S. Lewis's Christian Apologetics: Pro and Con (Leiden: Brill/Rodopi, 2015), 27-74; Peter S. Williams 'In Defence of Arguments From Desire'

www.peterswilliams.com/2016/11/02/in-defence-of-arguments-from-desire/; Joe Puckett Jr. The Apologetics of Joy: A Case for the Existence of God from C.S. Lewis's Argument from Desire (Cambridge: Lutterworth, 2013).

134 See: Peter S. Williams, A Faithful Guide to Philosophy (Eugene, Oregon: Wipf and Stock, 2019), chapters $8,14 \& 15$. 
135 As C. John Collins notes: 'Traditional Christian metaphysics put all these things together by describing God's initial creation - which produced all things - followed by his providential maintaining and ruling what he had made.' - Reading Genesis Well (Grand Rapids, Michigan: Zondervan, 2018), $267 \mathrm{ff}$.

See: Alister McGrath, I Believe: Exploring the Apostle’s Creed (Leicester: IVP, 1997), 29-36.

136 See: Paul Marston, 'Understanding the Biblical Creation Passages'

www.asa3.org/ASA/topics/Bible-Science/understanding_the_biblical_creation_passages.pdf; Matthew Barrett, Ardel B. Caneday and Stanley N. Gundry, ed.'s. Four Views On The Historical Adam (Grand Rapids, MI: Zondervan, 2013); J. Daryl Charles, ed. Reading Genesis 1-2: An Evangelical Conversation (Peabody, Massachusetts: Hendrickson, 2013); Charles Halton and Stanley N. Gundry, ed.'s. Genesis: History, Fiction, or Neither? Three Views On The Bible's Earliest Chapters (Grand Rapids, MI: Zondervan, 2015); J.B. Stump and Stanley N. Gundry, ed.'s. Creation, Evolution, And Intelligent Design (Grand Rapids, MI: Zondervan, 2017); John H. Walton, The Lost World Of Genesis One: Ancient Cosmology and the Origins Debate (Downers Grove, IL: IVP Academic, 2009); John H. Walton, The Lost World Of Adam And Eve: Genesis 2-3 and the Human Origins Debate (Downers Grove, IL: IVP Academic, 2015).

137 Michael J. Murray and Michael Rea, An Introduction to the Philosophy of Religion (Cambridge: Cambridge University Press, 2008), 211. See: John C. Lennox, Seven Days That Divide The World: The Beginning According To Genesis And Science (Grand Rapids, MI: Zondervan, 2011); Stephen C. Meyer, Signature in the Cell: DNA And The Evidence For Intelligent Design (New York: HarperOne, 2009); Charles B. Thaxton et al, The Mystery of Life's Origin: The Continuing Controversy (Seattle: Discovery Institute, 2020).

138 Alvin Plantinga, 'When Faith and Reason Clash: Evolution and the Bible' www3.nd.edu/ afreddos/courses/43150/plantinga.pdf.

139 See: Peter S. Williams, 'Is Christianity Unscientific?' https://youtu.be/mWiU2p_PIE8; Peter S. Williams, 'Is Christianity Unscientific?' Theofilos (2013), www.peterswilliams.com/wp-content/uploads/2013/07/Is-Christianity-Unscientific-Theofilos-Paper.pdf.

140 See: Peter S. Williams, 'A Universe From Someone - Against Lawrence Krauss' (2012)

www.bethinking.org/is-there-a-creator/a-universe-from-someone-against-lawrence-krauss; 'Carl Sagan: The Skeptic's Sceptic' (2008) www.bethinking.org/atheism/carl-sagan-the-skeptics-sceptic; 'In Search Of Innocence: Ghost in a Shell 2' www.peterswilliams.com/2016/02/09/in-search-of-innocence/; Peter S. Williams, Outgrowing God? A Beginner's Guide to Richard Dawkins and the God Debate (Eugene, Oregon Cascade, 2020); Steve Couch, Tony Watkins an Peter S. Williams, Back In Time: A Thinking Fan's Guide to Doctor Who (Southampton: Damaris, 2005); Steve Couch, ed. Matrix Revelations: A Thinking Fan's Guide to the Matrix Trilogy (Southampton: Damaris, 2003). 